\title{
Empathy versus Abstraction in Twentieth-Century German and Russian Aesthetics
}

\author{
Thorsten Botz-Bornstein \\ Tuskegee University
}

Follow this and additional works at: https://docs.lib.purdue.edu/clcweb

ర

Part of the Comparative Literature Commons, and the Critical and Cultural Studies Commons

Dedicated to the dissemination of scholarly and professional information, Purdue University Press selects, develops, and distributes quality resources in several key subject areas for which its parent university is famous, including business, technology, health, veterinary medicine, and other selected disciplines in the humanities and sciences.

CLCWeb: Comparative Literature and Culture, the peer-reviewed, full-text, and open-access learned journal in the humanities and social sciences, publishes new scholarship following tenets of the discipline of comparative literature and the field of cultural studies designated as "comparative cultural studies." Publications in the journal are indexed in the Annual Bibliography of English Language and Literature (Chadwyck-Healey), the Arts and Humanities Citation Index (Thomson Reuters ISI), the Humanities Index (Wilson), Humanities International Complete (EBSCO), the International Bibliography of the Modern Language Association of America, and Scopus (Elsevier). The journal is affiliated with the Purdue University Press monograph series of Books in Comparative Cultural Studies. Contact: <clcweb@purdue.edu>

\section{Recommended Citation}

Botz-Bornstein, Thorsten. "Empathy versus Abstraction in Twentieth-Century German and Russian Aesthetics." CLCWeb: Comparative Literature and Culture 9.2 (2007): <https://doi.org/10.7771/1481-4374.1220>

This text has been double-blind peer reviewed by $2+1$ experts in the field.

The above text, published by Purdue University Press (CPurdue University, has been downloaded 1670 times as of 11/ $07 / 19$.

This document has been made available through Purdue e-Pubs, a service of the Purdue University Libraries. Please contact epubs@purdue.edu for additional information.

This is an Open Access journal. This means that it uses a funding model that does not charge readers or their institutions for access. Readers may freely read, download, copy, distribute, print, search, or link to the full texts of articles. This journal is covered under the CC BY-NC-ND license. 


\section{PURDUE}

UNIVERSITY PRESS <http://www.thepress.purdue.edu>

\section{CLCWeb: Comparative Literature and Culture}

ISSN 1481-4374 <http://docs.lib.purdue.edu/clcweb> Purdue University Press (CPurdue University

CLCWeb: Comparative Literature and Culture, the peer-reviewed, full-text, and open-access learned journal in the humanities and social sciences, publishes new scholarship following tenets of the discipline of comparative literature and the field of cultural studies designated as "comparative cultural studies." In addition to the publication of articles, the journal publishes review articles of scholarly books and publishes research material in its Library Series. Publications in the journal are indexed in the Annual Bibliography of English Language and Literature (Chadwyck-Healey), the Arts and Humanities Citation Index (Thomson Reuters ISI), the Humanities Index (Wilson), Humanities International Complete (EBSCO), the International Bibliography of the Modern Language Association of America, and Scopus (Elsevier). The journal is affiliated with the Purdue University Press monograph series of Books in Comparative Cultural Studies. Contact: <clcweb@purdue.edu>

\section{Volume 9 Issue 2 (June 2007) Article 4 \\ Thorsten Botz-Bornstein, \\ "Empathy versus Abstraction in Twentieth-Century German and Russian Aesthetics" \\ <http://docs.lib.purdue.edu/clcweb/vol9/iss2/4>}

Contents of CLCWeb: Comparative Literature and Culture 9.2 (2007)

<http://docs.lib.purdue.edu/clcweb/vol9/iss2/>

Abstract: In his paper, "Empathy versus Abstraction in Twentieth-Century German and Russian Aesthetics," Thorsten Botz-Bornstein argues that Alexander Koyré has shown how the crisis of belief incited by Bacon, Montaigne, Pascal, and Descartes made that "man lost his place in the world." The German term Einfühlung (empathy) played an important role in the transformation of the relationship between the person and his/her world at the moment when modern science began to emerge. BotzBornstein examines the conceptual links between empathy and Verfremdung (in Russian ostranenie), and style by showing how German and Russian literary critics of the 1910 s attempted to retrieve the world with the help of these concepts. Among these theorists were Wilhelm Worringer, Adolf Hildebrand, Oskar Sievers and Russian Formalists such as Victor Shklovsky and Boris Ejxenbaum. BotzBornstein retraces the concept of Einfühlung from Schleiermacher through Theodor Lipps to positivism and he also reconsiders the Oskar Walzel's theory of aesthetics. Botz-Bornstein argues that a later generation of formalists managed to retrieve the world not in the form of a presence but of a trace or some other kind of elusive, dynamic structure, or style. The stylizing effect of ostranenie in skaz, for example, lets elements of "oral speech" shine through as a kind of "absent structure." 
Thorsten Botz-Bornstein,

"Empathy versus Abstraction in Twentieth-Century German and Russian Aesthetics"

page 2 of 9

CLCWeb: Comparative Literature and Culture 9.2 (2007): <http://docs.lib.purdue.edu/clcweb/vol9/iss2/4>

\section{Thorsten BOTZ-BORNSTEIN}

\section{Empathy versus Abstraction in Twentieth-Century German and Russian Aesthetics}

In the seventeenth century the person looses not only his/her central place the world but also the world itself. Alexander Koyré has shown how the crisis of belief incited by Bacon, Montaigne, Pascal, and Descartes made that "man ... lost his place in the world ... lost the world itself that offered him right of his existence and the object of his knowledge, and had to modify not only his fundamental conceptions but even the structures of his thought" ( $D u$ Monde clos... 10). According to Koyré, the world is lost, but it will be replaced. Man will exchange the lost center of his emotional and intellectual life with an abstract center which he still calls "God" or "Absolute Being." This center is not physical (not part of the "real" world) but metaphysical, that is, alienated from "real" world we are living in. The metaphysical God is abstract. The history of philosophy shows that the power of this abstract God is not infinite and that the new, abstract center cannot last forever. Newton's worldview and the work of modern science allow any centralized universe to appear as an idealistic illusion. Finally, one finds that the "world" as a calculable object of science cannot have a "human" center. The scientific world is "another world" which does not overlap with the everyday world of human beings. "Newton," Koyré writes in his Newtonian studies, "split our world in two [by] substituting our world of quality ... in which we live, and love, and die, by another world in which there is no place for man" (Newtonian Studies 23-24). Once again, man has lost his world. This time, however, it can be replaced by neither an idea nor by something concrete. The state of affairs resulting from this situation is often characterized as one of the estrangement of man from his world. Ilya Prigogine and Isabelle Stengers wrote that the "real world" (meaning the world of science) has become "estranged" and "utterly divorced from the world of life" (36).

We note that in the situation described by Koyré estrangement exists as a general condition transcending the purely socio-economical domain. Karl Marx, who borrowed the term Entfremdung (estrangement) from Hegel's philosophy of the law, drew attention for the first time to a degeneration of modern society by using this term in the sense of psychological alienation. According to Marx, Entfremdung appears there where the producers can no longer identify themselves and their own objectives with the products they produce. In a Marxian context, Entfremdung is not meant to reveal a general cultural crisis produced by increasing scientification of the world but, rather, the estrangement of the individual from society through industrialized production processes. The individual will be estranged because society has lost its historical mission of producing a world that is adequate to human conditions. The fact that man (I am referring here to both genders) sees the scientific, modern world as something "estranged" means that he/she has difficulty establishing any personal links with this world. His/her particularly human thoughts, ideas, and feelings are no longer reflected by this world which claims to be "real." There is no "feeling" and certainly no "empathy" as a possible relationship between_individuals and the world of science. The meaning of Einfühlung is that of identification with another's situation or motives. In any case, it is not just "feeling." Although Monroe C. Beardsley still defines the philosophy of empathy as a philosophy trying to propagate the idea "that human feelings are projected onto inanimate objects" (380), in fact, the concept of Einfühlung in the history of German aesthetics represents something ambiguous and complex (on this, see, e.g., see Morgan). By observing the development which transformed a world where Einfühlung was possible into a world of alienation (Entfremdung), we come across a notion which occupied, in fact, a central position in the theory of aesthetics at exactly the time when this shift took place. This is the notion of "alienation," Verfremdung in German and ostranenie in Russian. There is a link between Verfremdung and Entfremdung but it would be hasty to say that Entfremdung is produced by acts of Verfremdung. The world's Entfremdung has not been brought about by man through any conscious acts of Verfremdung. It has not been imposed directly upon the world by man in the same way he would impose a certain aesthetic form or a certain "style" on the world he is living in. As Koyré has shown, modern science did not change an already existing world by alienating it from its original state, but, rather, separated the human world from its own realm declaring that this scientific world should be considered as the only "real" world. The production of the estranged world is thus not due to an act of Verfremdung but to an act of creation.

One of the most influential books in the theory of aesthetics of the early twentieth century is Wilhelm Worringer's Abstraktion und Einfühlung (1959 [1908]). In this work, Worringer develops an aesthetic conception for which all art is divided into two categories: one which is due to an act of Einfühlung and one which is due to an act of abstraction. Worringer's understanding of these terms is special at least on one point: Einfühlung is seen as the active re-experiencing of another object but 
Thorsten Botz-Bornstein,

"Empathy versus Abstraction in Twentieth-Century German and Russian Aesthetics"

CLCWeb: Comparative Literature and Culture 9.2 (2007): <http://docs.lib.purdue.edu/clcweb/vol9/iss2/4>

requires a particular condition. Einfühlung can only take place as long as the individual possesses a "happy pantheistical relationship of confidence" ("glückliches pantheistisches Vertraulichkeitsverhältnis," Worringer 48) towards the world he/she is living in. Here, Worringer reinstates a view which corresponds with the traditional understanding of Einfühlung as an "Eins-fühlung" (felt unity) which was already current in German Humanism. Herder, for example, describes Einfühlung as a "happy making pan-psychic symbiosis with ingenious nature" (beglückende panpsychische Einsfühlung mit der sinnreichen Natur") (see Perpeet 398; see also Morgan, who draws attention to Johannes Volkelt's [1848-1930] concept of a "romantic fusion with nature"). Worringer says that only the person who identifies with the world can also re-experience it and this has one decisive consequence: while re-experiencing the world, a person re-experiences himself/herself since what he/she finds in the re-experienced object is always a projection of his/her own self. In this sense, Worringer claims, the act of Einfühlung is an act of self-affirmation (Selbstbejahung). The contrary of Einfühlung is abstraction. Abstraction consists in the act of choosing, among a variety of characteristics that an object can have, certain qualities and to negate others. Through abstraction, the object will no longer be "itself," concretely and immediately, but be represented by something "different" to which it can be linked only with the help of reflection. For Worringer, abstraction takes place when man feels discomfort and disquietude (Beunruhigung) in his/her world. This "disquietude" is due to a loss of a (pantheistical) centre, a loss which lets the individual perceive the world as an arbitrary constellation of forces and appearances. The person who feels uncomfortable in his/her world wants to establish a quiet centre (Ruhepunkt) by abstracting the disordered objects from their natural forms and contexts. He/she finds the world's lawful and necessary order in the form of an abstraction. The abstraction effectuated on the world is certainly an act of Verfremdung. Unlike Einfüh/ung, abstraction is not an affirmation of the self, but an affirmation of the other, of a purely abstract quantity which is neither "my self" nor somewhere "in my self." It is an affirmation of "the strange," of das Fremde which does not come from here and not even from elsewhere: it exists all alone and only for itself.

Although the concept of Einfühlung was treated theoretically by several philosophers throughout the nineteenth century, the real aesthetics of Einfühlung was developed mainly by Theodor Lipps and his followers. Lipps's aesthetics represents the culminating point of subjectivist philosophy. Subjectivist philosophy holds that aesthetic examination should not focus on the object but on the subject of understanding; for an empathizing subjectivist it is not the form of the aesthetic object but the disposition of the contemplator which constitutes the most decisive moment in human understanding. Lipps focuses on the immediacy of a certain "feeling" that is produced in aesthetic experience, a feeling which directly communicates an ideal contents of an aesthetic work: "I do not only represent the ideal 'I' [of an artist], but I have or 'live' (erlebe) it in the aesthetic object. This also causes a heightening of the emotional effect. My feeling towards this ideal ' $\mathrm{I}$ ' is not only real, but also has the immediacy and the force which follow necessarily from this particular aesthetic reality of the ideal 'I'" (368; unless indicated otherwise, all translations are mine). However, the immediacy (Unmittelbarkeit) of aesthetic understanding which is supposed to be produced through Einfühlung is suspicious. If, as Lipps suggests, perception always goes "through" the subjective mind of the contemplator, this means that the object of aesthetic contemplation is never perceived as it "really is:" it is always verfremdet through the subjectivity of the perceiver. This means that Einfühlung and Verfremdung are not opposed to each other but that Einfühlung always implies a moment of Verfremdung. And the same must be true for Worringer's opposition of empathy and abstraction. Worringer depicts the entire history of art as an activity shifting between these two aesthetic principles. However, he neglects that neither of the two principles can appear independent of the other. An Einfühlung which re-experiences an object always abstracts from this object since the object will not enter "directly" into the contemplator's mind. At the moment, however, aesthetics actually tries to make a clear decision in favor of one or the other conception, and it must face a radical consequence: it stops being aesthetics. This happened with positivism (positivism is identified here in the first place with the philosophical thinking of Auguste Comte who developed methods to understand the world with the help of scientific methods, thus annulling the difference between the natural and social sciences and the humanities). In positivism we observe how the radicalism of the choice -- which declares itself to be on the side of one extreme -- renders it so difficult to say which extreme it has finally chosen. When the positivist claims that we can perceive any appearance with the "innocence of newborn children" (Hildebrand 15) the question is: does the positivist suggest here an aesthetics of radical Einfühlung or of radical abstraction? As a matter of fact, the suggestion encompasses both, as becomes clear in Lipps. What Lipps calls "positive ästhetische Einfühlung" ("positive aesthetic empathy") lays the ground for an abstracting aesthetical approach.

This is also a more or less clear-cut outline of later positivism which appears as a curious fusion of 
Thorsten Botz-Bornstein,

"Empathy versus Abstraction in Twentieth-Century German and Russian Aesthetics"

CLCWeb: Comparative Literature and Culture 9.2 (2007): <http://docs.lib.purdue.edu/clcweb/vol9/iss2/4>

Einfühlung and abstraction. Outer appearances that enter the mind of the empathizing positivist in an "unfiltered" way represent abstractions of the world (they need to be "abstract" if the "purity" of the Einfühlung shall be guaranteed). We recognize that Einfühlung and abstraction are two overlapping extremes of one and the same philosophical system. Positivism, while looking for an alternative of a subjectivist Einfühlung, remained particularly close to the very concept it was combating. An alternative, powerful enough to twist philosophy out of the process of eternal inversions of the system abstraction-Einfühlung, arises only in post-positivist philosophy. The concept of Einfühlung intermingles with the concept of abstraction on the most basic level. The fact that a "pure" Einfühlung is impossible is recognized by post-romantic philosophy, particularly during a phase in which subjectivism was weakened but not yet re-established by positivism. At moments where subjectivist ideas were confronted with the "irrational" phenomenon of the hermeneutic circle, one created an "undermined," ambiguous concept of Einfühlung. Schleiermacher continues to believe in the validity of subjectivist judgments even after having considered hermeneutic questions. However, for Schleiermacher the concept of Einfühlung stops being a purely subjectivist Einfühlung. Schleiermacher finds that creativity is hermeneutically circular because a creating artist has "also seen the single first, then proceeding to the general" (104). Every interpreter of a work of art needs to duplicate the creative process of the artistic production by following the development from the general to the individual. In the end, Einfüh/ung moves from a passive re-experiencing activity to an active process of "reconstruction" which Schleiermacher calls "nachbilden." Schleiermacher's successor, Dilthey, develops the reconstructive tendency. Dilthey calls Schleiermacher's Nachbilderei (recreation) Nachkonstruiererei (reconstruction): "The way humanities encounter reality in human history is not a copy of a reality which exists outside humanities. Such a reality cannot be established by knowledge (Erkennen), but only be felt (nachfühlen), reconstructed (nachkonstruieren)" (8). In German aesthetics, Dilthey's ideas -- as well as those of classical hermeneutics -- remain present. However, if we compare the writings of Hildebrandt, Wölfflin, and Walzel with the ideas of German aesthetics from Schleiermacher to Lipps, we notice that aesthetics lost its innocence. It lost its innocence by going through a movement by which Dilthey was deeply affected: positivism. Positivism's intention was to leave behind the entire hermeneutic heritage and to define the act of understanding as an act of Einfühlung as direct as scientifically controllable.

Hildebrand postulates that we always already have a certain idea of the Dasein (existence) of a certain object. However, it is not enough to consider the individual event in a general context because these general ideas might be conventionalized and standardized conceptions of the world. This does not mean that the general is false in any case (as it is for empiricists) but the main fallacy consists in the fact that "the general" can be "dead." If our "generalization" of individual facts and events follows only the standardized rules of the conventional, the process of Einfühlung will never lead to a living experience but only reaffirm a banalized, official image of the world. Hildebrand asks for a Verfremdung of the context of an object contemplated and sees this Verfremdung as a necessary precondition for a successful Einfühlung. With Hildebrand's ideas, pronounced at the beginning of the modern age, we are confronted with a paradoxical constellation of Entfremdung and Verfremdung. The modern world of technology is not entfremdet (alienated in the first order) from the individual because it has been verfremdet (alienated in the second order). Entfremdung appeared exactly at that moment when the contact between humanity and the world was too direct, when it was reduced to a pure Einfühlung. More precisely, the "happy and pantheistical confidence relationship" which, according to Worringer, still used to be the basis of every act of Einfühlung has not been abolished but it has been re-described in positivism by means of abstract concepts. Einfühlung has become a pure abstraction to the extent that technology has become a second nature; and this is the real Entfremdung. For Worringer (as for Vassily Kandinsky, who, in his Concerning the Spiritual in Art drew on Worringer [see Rickey 25]), this became particularly obvious in art. In general, "art had ceased to have the power to change people's lives or even to speak to the in meaningful terms" (Gluck 154). The real, concrete world is lost but another set of scholars will attempt to retrieve it. To understand this we will first have to analyze more closely the theory of Verfremdung and its German and Russian interactions.

If we want to understand the concept of Verfremdung with all its theoretical and philosophical implications, we need to examine the aesthetic theory were it was developed: Russian Formalism. Russian Constructivist art (one of the artistic branches of the Formalist/Futurist movement) was exposed to the influence of Worringer's Abstraktion and Einfühlung and the most prominent constructivist artist, Gabo, appreciated Worringer's ideas (like many others, Gabo has probably been confronted with Worringer's thoughts via Kandinsky). The relationship of the Russian Formalists with positivism, on the other hand, is ambiguous. For example, René Wellek is convinced that the Russian Formalists "were 
Thorsten Botz-Bornstein,

"Empathy versus Abstraction in Twentieth-Century German and Russian Aesthetics"

CLCWeb: Comparative Literature and Culture 9.2 (2007): <http://docs.lib.purdue.edu/clcweb/vol9/iss2/4>

positivists with a scientific, almost technological ideal of literary scholarship. Their concept of form seems to make it a sum of relations between elements. Though their tools were immeasurably finer, they returned to the old rhetorical formalism" (67). The initial activities of the OPOJAZ group (the main group $f$ thinkers who developed early Russian Formalism), were to a large extent inspired by the anti-positivist fashion that had existed earlier in Europe. Still, because of the scientific character of the whole Formalist tradition, many scholars will be disinclined to identify Russian Formalism with an extension of Western anti-positivism. Things look different when one traces back the Formalist ideas to one of their main sources of western inspiration, to Oskar Walzel. Walzel was -- similar to Eduard Sievers and Franz Saran -- an honorary member of the St. Petersburg State Institute for the History of Arts, an institution which was crucial for the development of OPOJAZ. Walzel studied Worringer's ideas and recognized, like Hildebrand, the link between an all too radical concept of Einfühlung (which he found "impressionistic") and positivism. About positivism he writes: "But the one who binds his hands by declaring that only the point of view of the unique and of re-experience be valid, will stop at the factual exterior and can only produce incoherent data" (19). Impressionism wanted to paint nature "as it really is" but "by annulling all representations, impressionism borders on positivism" (58). Positivism and impressionism are linked through a circular shortcut. Attempts of escaping the circle will only invert the system. For Walzel, Expressionism is a typical example of such an inversion when he asks: "Is not Expressionism only a symptom of the return that I have taken as a point of departure? Tired of the imitation of nature, the artist looks for the essence of that notion of form from which the 19th century had almost been estranged" (73). The links between Walzel, the German intellectual environment surrounding him, and the Russian Futurists are not based on speculation. Walzel's book Die künstlerische Form des Dichtwerks was translated into Russian by Viktor Zhirmunsky, one of the most prominent representatives of the Russian Formalist tradition. Although Walzel's conception of the literary work turned out to be incompatible with later Formalist ideas on literature, his influence remained decisive. Equally influential were the ideas of Walzel's colleagues, Sievers and Saran, whose Ohrenphilologie (the philology of hearing) inspired Futurist experiments with unexpected phonetic aspects of a thing (Shklovsky) and Ejxenbaum adopted elements of Sievers identification of melodies with intonation (see Steiner 200).

Futurism materialized some of Walzel's most fundamental ideas, whose new theory of interpretation refused impressionism, expressionism as well as positivism and radically negated all philosophical variations of Romantic Einfühlung. Futurism fulfils this project by refusing Romantic mysticism which, at that time, was prominent in the form of "bourgeois impressionism" (see Trotzky's "Majakovsky and Russian Futurism" qtd. in Erlich 169) and the scientific mysticism of the positivists. Futurist poetry, literature, and poetics move away from impressionist symbolism and all other concepts which try to make man re-experience the world through more or less sophisticated forms of Einfühlung. They do this by developing the concept of Verfremdung (ostranenie). Another way to express this is to say that in Futurism, the device of ostranenie is supposed to give the world back to the individual by putting him/her back into the world's centre. The Cubo-Futurist Alexei Kruchenykh wrote: "Our new devices teach a new understanding of the world, shattering the impoverished constructions of Plato, Kant, and other 'idealists,' where man stood not at the centre of the universe, but behind the fence" (75). "Conventional" art is based on "re-experience" or "co-experience" and this is the reason why it has moved away from the "real world." The twenty-two-year-old Sergei Eisenstein strolls through St. Petersburg and suddenly recognizes that "art" (theatre) enables man to co-experience great emotions fictitiously, to feel a hero like Franz Moor fictitiously. He concludes by saying that this "infernal mechanics" is "downright dangerous" (Eisenstein in Taylor 13). Real art, Futurist art and film, should give man not fictions, but the world.

The Futurists are opposed to their predecessors and last "idealists," the symbolists. They no longer aim to grasp the "world" in the form of its "essence" through the device of the symbol as is recommended, for example, by the symbolist Dimitry Merezhkovsky. Strictly speaking, the world is lost and there is no way of getting it back, at least not "directly" in the form of an idea or an abstract symbol. There is, however, a way of putting the individual back into the centre of the world: he/she has fallen out of the world not because the world has been removed from him/her and is now "elsewhere;" on the contrary, the world is lost because it is too close to humanity. This is the world that we encounter in everyday life and which is constituted by the functional laws of our routinized, modern life of technology. Humanity can get back the world neither by trying to re-experience it, nor by using the more sophisticated device of changing the relationship between the individual and the world into a symbolical contact of hints and gestures. For Futurists and Formalists, the source of Entfremdung of the individual from his/her world is different. Roman Jakobson said (under Husserlian influence) that the main 
Thorsten Botz-Bornstein,

"Empathy versus Abstraction in Twentieth-Century German and Russian Aesthetics"

CLCWeb: Comparative Literature and Culture 9.2 (2007): <http://docs.lib.purdue.edu/clcweb/vol9/iss2/4>

problem of estrangement is that the connection between signans and signum is too automatized (see Pomorska 36). Within this automatization, the act of symbolization takes place on standardized, wornout rails that preexist between the symbolizer and the symbolized object. Instead of accepting their preexistence, we should always recreate them ourselves anew every time we attempt to "see" the world. The discovery of the world through the individual, through his/her vision and from his/her point of view is supposed to take place through a disautomatization of the symbolizing relationship between the individual and the world. For Futurists, the world needs to be verfremdet in order to be felt again as a "world." Ostranenie, as Shklovsky said, makes "the stone stony" again (Shklovsky, Theory of Prose 6). The problem is that the destruction of the habitual logic of associations (Shklovsky) can adopt a logical character itself. When Kruchenykh spoke of transrational language as a language which, opposed to all rules of common life, follows its "own rules," one must ask if these rules will not also become "common" one day (see Kruchenikh). This means that Futurism created rules by refusing them which is the reason why, in the end, its aesthetics, by following rules as technical devices, adopted a very technical character.

Benedetto Croce described Futurism as a project that would necessarily "run out of contents" because its stubborn anti-historicism would turn it into a heartless aesthetics of technical devices: "While the futurist, like the utopist, pretends to skip over history and, like the latter, pretends to found a new society on paper, the former then creates a new poetry only out of pretension; just as the utopist is unable to find a new rule, the futurist is unable to find the new rhythm which would truly be a rhythm and not merely the tortured calculation of an arhythmical rhythm" (7-8). Futurists did not find the "real rhythm" of aesthetic expression but produced, by "smashing the rhythms" (Wellek 263), a rhythm with an artificially constructed style. Futurists did not produce style but followed grammatical, abstract rules. For Futurists and Formalists, style was not the style of the world (present or past) but the abstract, utopian style of the future, which we perceive when we separate art from byt (byt, this untranslatable Russian word signifies the "conventional" as well as "life," the everyday life to which Futurist art opposes itself). In other words, Futurism did not want to derive the future from the past but to create the future out of nothing. The idea of "stylization" (which is always stylization of something historically existing) was, from the beginning, out of the question. Formalism and Futurism refused to consider expressive style of individuals and, as said Jakobson, "disguised the 'ego' of the lyric poet under a pseudonym" (280). For formalists, style is purely general; it is not a style expressing an individual Weltanschauung. This is one more reason why with Formalism the "world" is once again lost. In Futurism and Formalism, the concept of Einfühlung was supposed to be overcome without turning into an abstract, scientific concept of positivistic Einfühlung. However, the Formalist project which sees the world through ostranenie bears no "philosophical" input: the "structure" of the world that we discover when we see the world as a constellation of devices is a purely formal phenomenon and involves no existential and ontological questions. This implies the separation of Formalist ideas from Walzel's conception of artistic form. According to Walzel, "form" is dependent on what he calls "spiritual presuppositions" which are not embraced by a redescription of form through Kunstgriffe (plural of "device of artistry"; Kunstgriff is the German translation for the Russian priëm "device"). Ostranenie combated Einfühlung successfully in the anti-positivist way that Walzel had recommended. However, the philosophy of ostranenie never reached the all-encompassing, existential level that Einfühlung, with its classical heritage aiming at the establishment of a "natural" link between Einfühlung and Eins-fühlung, has always had. In turn, Formalism developed in a similar way on the German side, only much earlier. Walzel's predecessors, the German aestheticians who followed Gottfried Semper's call for an aesthetic stylistics which sees art as an interplay of material and technique, found themselves in a position similar to that of the Formalists. Alois Riegl (who later reformed Semper's materialistic aesthetics) wrote about the consequences of Semper's influence in Germany: "When Semper said, 'what is important in the development of an artform is also material and technique,' the Semperians immediately thought that the art form would simply be a product of material and technique. 'Technique' quickly became the most popular slogan; it soon acquired the same meaning as 'art' and finally it was pronounced even more than the word art" (vii).

Consequently, Russian critics of Formalism (especially Bakhtin and his circle) interpreted, although with slight distortions, Semper's stylistic as a precursory movement of positivism. Medvedev wrote: "Utilitarian positivism made a sturdy nest for itself in the scholarship of the second lie half of the nineteenth century ... Here they relied on authority of Gottfried Semper, who characteristically defined a work of art as a mechanical product, consisting of a particular purpose, raw material, and technique" (Medvedev, Formal Method 9). The Russian Formalists and Futurists radicalized Semper's materialistic aesthetics and this is no surprise. After all, their muse was the muse technè. What René Wellek said 
Thorsten Botz-Bornstein,

"Empathy versus Abstraction in Twentieth-Century German and Russian Aesthetics"

CLCWeb: Comparative Literature and Culture 9.2 (2007): <http://docs.lib.purdue.edu/clcweb/vol9/iss2/4>

about the Russian Formalists' Czech counterparts and their attitude in regard to the option of "style or technology" is also true for the Futurists: their poetics was not due to a refined social environment but to the rude games of young people who have no intellectual tradition. An alternative approach to ostranenie would consist in seeing it as a means of "stylizing" the world in order to create an ironic distance between the world and its contemplator. Futurism and Formalism themselves -- in their later phases -- had at times considered this way of designing an aesthetics of ostranenie. Shklovsky, in some of his novels, represents the idea of "irony" as a device which creates a distance between reader and narrator (man and the world), and he does so by basing his aesthetics on the device of ostranenie. Further, in Yuri Tynianov's and Jakobson's version of Formalism the tension between synchrony and diachrony represents the main driving force of cultural evolution. This driving force is dependent upon ostranenie: any "system" must constantly be de-systemized in order to evolve. In the end, however, dynamics will not remain dynamic to the same extent as ostranenie will not remain verfremdend. Medvedev brought forward the most apt criticism of Formalism when writing: "Tynianov's dynamics remains a dynamics an und für sich, a sterile, empty, non-sensical notion" ("The Collapse" 415). The same is true for ostranenie. However, the dynamic intermediary between synchrony and diachrony is style (as style is for Charles Bally the dynamic intermediary between langue and parole). Such a dynamical concept of style was a matter neither of Futurism nor of classical Formalism, because, like all avant-garde movements, they feared that an occupation with style would throw them back into historicism. Another developer of Tynianov's idea of dynamism is Yuri Lotman. Out of Lotman's preoccupation with a "historical structure" (which is not to be mistaken for the structure of history") flows the definition of a half-contingent and half-necessary structure that resides between diachronical and synchronical aspects of human society. Lotman suggests that what he calls a "literary fact" cannot be grasped through absolute rules but only through a phenomenon which constantly creates its own rules or its own language: "The [literary] object to be created is settled in the 'present-future.' Having by chance appeared in the present because of the coincidence of circumstances, it can turn out to be a source of a new lawfulness, it can create a new language (141).

Other Formalists made similar remarks by alluding to a famous phenomenon current in Russian literature which comes, by its nature, very close to stylization: skaz. The Russian word skaz is a technical term that is used in Russian literary criticism and elsewhere in order to characterize a text which an author has introduced into another text and which he presents as if it is a text not stemming from himself/herself but from an imaginary author. Through skaz, an author presents a text within another text by "reworking" it by means of stylization and ostranenie. A successful skaz-like stylization can only take place as long as the skaz remains dynamic. Ejxenbaum refers to the metaphor of game as a principal means for the preservation of the dynamic power of skaz. In "How Gogol's Overcoat is Made" he writes about Gogol's use of the skaz: "The real dynamics, and even through this also the composition of his works, consists of the construction of skaz, this means of the play of language" (412). Victor Vinogradov has shown that this play of language can, in fact, be considered as an act of stylization. In "Skaz in Stylistics" he examines Futurist linguistic "deformations" by means of which Futurist poets tried to create their "new language" and decides to call these acts of stylization an "aesthetic game:" "A movement of word lines which are not held by a logical leading line, which contains jumps and cuts, boring repetitions of the same words, constant slips of the tongue and defective formations imitating various forms of destruction of speech functions - all this is used as a material for an aesthetic game" (198). Stylization creates a new, "strange" language but not by simply forcing the code of ostranenie onto the "normal," already existing, language. On the contrary, the process of stylization and ostranenie is as dynamic as a game. Vinogradov shows this by analyzing the phenomenon of skaz. A written text can be transformed into skaz by letting it "represent" oral speech. This is done by means of ostranenie. However, ostranenie should not simply mean to force the code of oral speech onto the written text. On the contrary, the result of the ostranenie is neither "oral speech" nor "written speech" but skaz which is something completely new: "Oral, living, speech is there, where there is no skaz; but where skaz is obvious one can sometimes find unusually few specific elements of oral speech" (176). In skaz, which represents oral speech, there is no real presence of oral speech. Rather, the stylizing effect of ostranenie lets elements of "oral speech" shine through as a kind of "absent structure."

In conclusion, in Formalism the text is "made strange" through the device of ostranenie and stylization. Lotman and Uspensky complicate this conception by presupposing the existence of a "trace" which appears as a result of stylization and which represents the author's silent voice speaking through the device of stylization. Here the result of ostranenie is not the creation of an absolutely strange language of technological devices; on the contrary, the entfremdete language is produced or 
Thorsten Botz-Bornstein,

"Empathy versus Abstraction in Twentieth-Century German and Russian Aesthetics"

page 8 of 9

CLCWeb: Comparative Literature and Culture 9.2 (2007): <http://docs.lib.purdue.edu/clcweb/vol9/iss2/4>

"written," in spite of its transformation through the ostranenie, by an einfühlende author who leaves his "trace" in the text. Einfühlung is here not simply transformed into abstraction but both Einfühlung and abstraction are included in an alternative that is called ostranenie. The world that had been lost has been retrieved. However, the world, the object of man's the individual's knowledge which also determines his/her most fundamental conceptions and even the structures of his thought has been retrieved not in the form of a presence but as a trace or some other kind of elusive structure which is neither abstract nor empirical-concrete. The closed circular system leading from Einfühlung to abstraction has been fractured and the perception of the world is dynamic.

\section{Works Cited}

Beardsley, Monroe C. Aesthetics from Classical Greece to the Present: A Short History. New York: Macmillian, 1966.

Croce, Benedetto. Estetica come scienza dell'espressione e linguistica generale. Teoria e storia. Bari: Laterza, 1922.

Dilthey, Wilhelm. Der Aufbau der geschichtlichen Welt in den Geisteswissenschaften. Frankfurt: Suhrkamp, 1974.

Doležel, Lubomir. "Narrative Composition: A Link between German and Russian Poetics." Russian Formalism. Ed. Stephen Bann and John E. Bowlt. Edinburgh: Scottish Academic P, 1973. 73-84.

Erlich, Victor. Russian Formalism: History, Doctrine. New Haven: Yale UP, 1975.

Ejxenbaum, Boris. "Kak sdelana shinel' Gogolja." 1926 Russkaja proza. Ed. Boris Ejxenbaum and Jurij Tynjanov. The Hague: Mouton, 1963. 149-65.

Gluck, Mary. "Interpreting Primitivism, Mass Culture, and Modernism: The Making of Wilhelm Worringer's Abstraction and Empathy." New German Critique 80 (2000): 149-69.

Hildebrand, Adolf. Das Problem der Form in der bildenden Kunst. Strassburg: Heitz, 1918.

Jakobson, Roman. "On a Generation which Squandered its Poets." Language in Literature. Ed. Krystyna Pomorska and Stephen Rudy. Cambridge: The Belknap P of Harvard UP, 1987. 273-300.

Koyré, Alexandre. Du Monde clos à l'univers infini. Paris: PU de Paris, 1962.

Koyré, Alexandre. Newtonian Studies. Trans. Leonora Cohen. Chicago: U of Chicago P, 1968.

Kruchenykh, Alexei. "New Ways of the Word." Trans. Anna Lawton and Herbert Eagle. Russian Formalism through Its Manifestoes, 1912-1928. Ed. Anna Lawton and Herbert Eagle. Ithaca: Cornell UP, 1988. 69-78.

Lipps, Theodor. Von der Form der ästhetischen Apperzeption. Halle: Niemeyer, 1902.

Lodder, Christina. Russian Constructivism. New Haven: Yale UP, 1983.

Lotman, Yuri. "Zur Rolle der zufälligen Faktoren in literarischer Evolution." Semiotics of Culture. Ed. H. Broms and R. Kaufman. Helsinki: Arator, 1988. 139-50.

Medvedev, Pavel. Formal'nyj metod v literaturovedenii. Leningrad: Priboi, 1928.

Medvedev, Pavel. "The Collapse of Formalism." Language and Literary Theory. Ed. Lubomir Doležel, Benjamin Stolz, and I.R. Titunik. Ann Arbor: U of Michigan P, 1984. 405-42.

Medvedev, Pavel. The Formal Method of Literary Scholarship. Cambridge: Harvard UP, 1985.

Morgan, David. "The Enchantment of Art: Abstraction and Empathy from German Romanticism to Expressionism." Journal of the History of Ideas 57.2 (1996): 317-41.

Perpeet, Wilhelm. "Einfühlungsästhetik." Historisches Wörterbuch der Philosophie. Ed. J. Ritter, K. Gründer, G. Gabriel. Basel: Schwabe, 1972. Vol. 2, 397-400.

Pomorska, Krystyna. Russian Formalist Theory and Its Poetic Ambiance. Paris: Mouton, 1968.

Prigogine, Ilya, and Isabelle Stengers. Order out of Chaos: Man's New Dialogue with Nature. London: Fontana, 1985.

Rickey, George. Constructivism: Origins and Evolution. New York: Braziller, 1967.

Riegl, Alois. Stilfragen Grundlegungen zu einer Geschichte der Ornamentik. 1893. Hildesheim: Georg Olms, 1975.

Schleiermacher, Friedrich. Hermeneutik und Kritik. Frankfurt: Suhrkamp, 1977.

Shklovsky, Viktor. Sentimental'noye puteshestviye. Leningrad: Atheneum, 1924.

Shklovsky, Viktor. O teorii prozy. Moscow, Leningrad: Krug, 1925.

Shklovsky, Viktor. A Sentimental Journey: Memoirs 1917-1922. Trans. Richard Sheldon. Ithaca: Cornell UP, 1969.

Shklovsky, Viktor. Theory of Prose. Trans. B. Sher. Normal: Dalkey Archive P, 1990.

Steiner, Peter. From Formalism to Structuralism: A Comparative Study of Russian Formalism and Prague Structuralism. Ann Arbor: U of Michigan Microfilms International, 1979.

Taylor, Richard, ed. Eisenstein Writings 1922-1934. Trans. Richard Taylor and William Powell. London: British Film Institute and $U$ of Indiana $P, 1988$.

Uspensky, Boris. A Poetics of Composition. Berkley: U of California P, 1973.

Vinogradov, Victor. "The Problem of Skaz in Stylistics." Texte der russischen Formalisten. Ed. J. Striedter. München: Fink, 1969. 172-202.

Walzel, Oskar. Das Wortkunstwerk: Mittel seiner Erforschung. Heidelberg: Quelle and Meyer, 1968.

Wellek, René. Concepts of Criticism. New Haven: Yale UP, 1963.

Worringer, Wilhelm: Abstraktion und Einfühlung. München: Piper, 1959.

Author's profile: Thorsten Botz-Bornstein teaches philosophy at Tuskegee University. Botz-Bornstein's interests in research include Russian formalism and semiotics in Russia and the Baltic countries. He has also been researching 


\begin{abstract}
Thorsten Botz-Bornstein,
"Empathy versus Abstraction in Twentieth-Century German and Russian Aesthetics"

page 9 of 9

CLCWeb: Comparative Literature and Culture 9.2 (2007): <http://docs.lib.purdue.edu/clcweb/vol9/iss2/4>

in Japan, in particular on the Kyoto School on the philosophy of Nishida Kitarô. In addition to his articles in journals, his book publications include Place and Dream: Japan and the Virtual (2004), Films and Dreams: Tarkovsky, Sokurov, Bergman, Kubrik, Wong Kar-wai (2007), Vasily Sesemann: Experience, Formalism and the Question of Being (2006), and Virtual Reality: The Last Human Narrative? (2007). E-mail: <tbotz@tuskegee.edu>
\end{abstract}

